\title{
Anatomical Indicators of Dominance between the Coronary Arteries of Dogs
}

\author{
Indicadores Anatómicos de la Dominancia en las Arterias Coronarias de Perros
}

\begin{abstract}
"Carla Lívia Santos de Oliveira; "Gustavo Serra David; *Michelly de Oliveira Carvalho; "Débora Dornelas; "Sandra Araújo; "Nailton Cavalcante da Silva; "* Cristiane Regina Ruiz ** Juliana Ruiz Fernandes \& "Nader Wafae
\end{abstract}

OLIVEIRA, C. L. S.; DAVID, G. S.; CARVALHO, M. O.; DORNELAS, D.; ARAÚJO, S.; DA SILVA, N. C.; ; RUIZ, C. R.; FERNANDES, J. R. \& WAFAE, N. Anatomical indicators of dominance between the coronary arteries of dogs. Int. J. Morphol., 29(3):845-849, 2011.

SUMMARY: In humans, the right coronary artery is dominant. However, we did not find any citations in the literature concerning anatomical indicators of dominance among dogs. We used 30 hearts from mongrels of both sexes, fixed in 10\% formalin. The branches of the coronary arteries were dissected with special attention to the levels that were considered to be reference points. In $96.7 \%$, the circumflex branch of the left coronary artery reached or went beyond the crux cordis. The subsinuosus interventricular artery, ended before reaching the apex in 21 cases, at the apex in five cases and after the apex in four cases. The paraconal interventricular artery, ended before reaching the apex in two cases, at the apex in 11 cases and after the apex in 17 cases. The region of the heart apex was irrigated by branches of the left coronary artery, through the paraconal interventricular branch or through both of the interventricular branches. The mean length and number of ventricular branches of the left coronary artery were greater than those of the right coronary artery. The subsinuosus interventricular branch is a branch of the circumflex branch of the left coronary artery. In the hearts of dogs, the left coronary artery is dominant. The dominance pattern in dogs is different from the dominance pattern in human that is mentioned in the specialized literature.

KEY WORDS: Morphology; Dog hearts; Circulation; Coronary arteries.

\section{INTRODUCTION}

The frequency of using coronary arteries from dogs in experimental studies has increased over recent years. Many of these studies had the aim of evaluating future applications in human hearts. Thus, the protective action of free radicals in coronary arteries following ischemia and reperfusion was studied (Sukmawan et al., 2007); investigated adrenergic activation in the right coronary artery flow following hypoxia (Setty et al., 2008); evaluated the action of endogenous hydrogen peroxide for vasodilatation of the coronary artery (Yada et al., 2007; Kawasumi et al., 2007); and studied the action of cell components for protecting cardiac cells in experimental infarcts (Del Rio et al., 2008); and examined the flow velocity during reperfusion following ligature of the coronary artery (Han \& Wei, 2008).

We believe that it would be important to contribute towards these researchers work by providing morphological reports on the coronary arteries in dogs, with regard to their variations and similarities to differences from human coronary arteries.

One matter on which we did not find any citations in the literature concerned the anatomical indicators of possible dominance between the coronary arteries in dogs.

In a study on human hearts (Schlesinger, 1938), considered that the reference points indicating dominance consisted of determining which coronary artery supplied the posterior (subsinuosus) interventricular branch and which branches went beyond the crux cordis, i.e. the meeting point between the interatrial, posterior (subsinuosus) interventricular and coronary sulci. Since then, other criteria have also been suggested: the lengths of arteries like the right coronary and left marginal branch (Baroldi \& Scomazzoni, 1967); the layout of the arteries at the apex of the heart (James, 1961); the length of the paraconal

* Anatomy Laboratory of the School of Medicine of the Central Plateau, FAMEPLAC, Brasília Siga Área Especial 02, Brasília, Brazil.

${ }^{*}$ Centro Universitário São Camilo - SP, Av. Nazareth, 1501, São Paulo, Brazil. 
interventricular artery (Ilia et al., 2001); and the number of branches to the ventricles (Vieira et al., 2008). Our aim was to investigate the various indicators suggested, in order to indicate which coronary artery is dominant in the hearts of dogs.

\section{MATERIAL AND METHOD}

The material used in this study consisted of 30 hearts from mongrels of various ages and both sexes. The hearts had been fixed and conserved in 10\% formalin. They came from dogs that were used within the Discipline of Surgical Technique of the School of Medicine of FAMEPLAC in regular classes within the medical course. These animals had been sacrificed in accordance with the technical standards of the Regional Council of Veterinary Medicine and the Society for Animal Protection.

After removing the hearts from the animals chests, the specimens were washed and any coagulated blood present was removed. The coronary arteries were identified and, to better define the arteries and their branches, we injected red neoprene latex into the arteries of some specimens. Following this, we dissected the arteries as far as the macroscopically visible ends of their branches, under the pericardium.

Biometry was performed, using a metal wire laid out along the arteries and their branches, in order to subsequently transfer the measured length to a universal mechanical pachymeter (Digimess), where the measurements were realized.

The crux cordis reference point adopted in this study corresponded to the intersection of the interatrial, subsinuosus interventricular and coronary sulci.

\section{RESULTS}

With the aim of bringing together elements that might clarify the dominance between the coronary arteries, we concentrated on the following locations: subsinuosus interventricular sulcus (posterior interventricular sulcus), crux cordis (meeting point of the coronary, subsinuosus interventricular and interatrial sulci), apex of the heart and ventricular margins. Another indicator that we analyzed, and which we are proposing, consisted of observing the total number of ventricular branches issued by each of the coronary arteries.
Subsinuosus interventricular sulcus (posterior interventricular sulcus). The subsinuosus interventricular sulcus was always occupied by the subsinuosus interventricular branch, which was the final division of the circumflex branch of the left coronary artery (100\%). In the lower part of the sulcus, we observed the presence of the paraconal interventricular branch (Fig.1), which is also a branch of the left coronary artery $(56.7 \%)$.

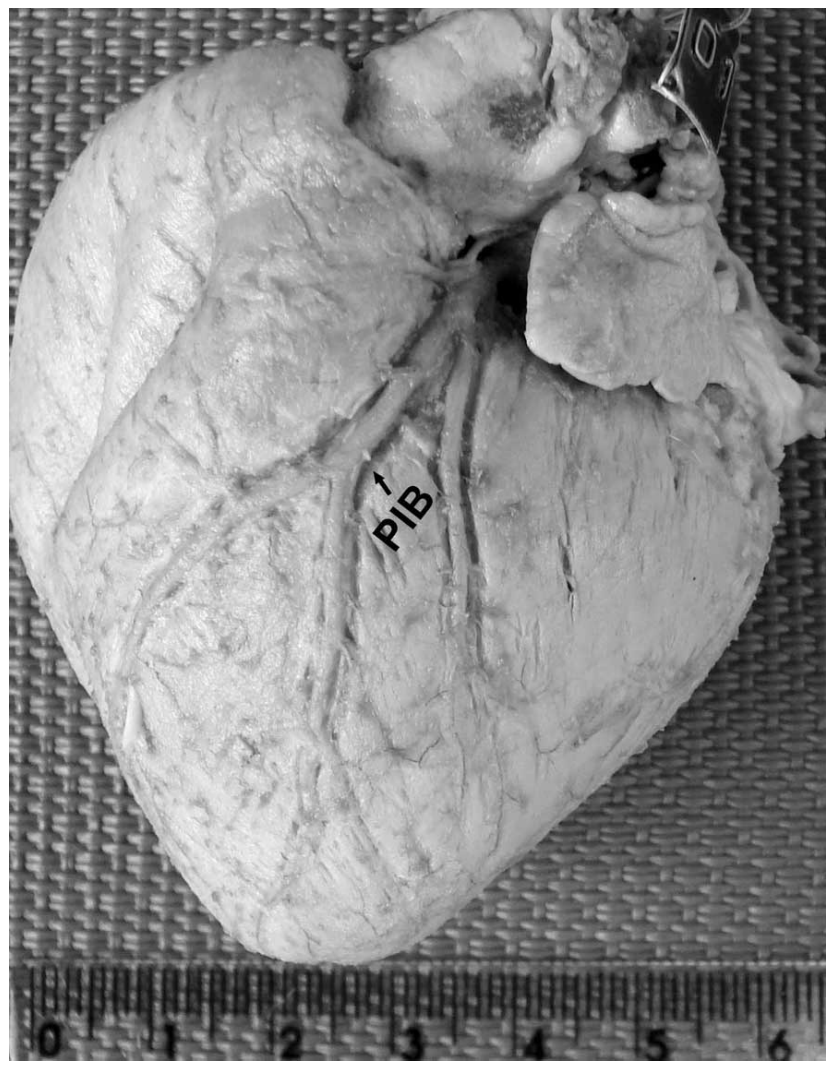

Fig. 1. Paraconal Interventricular branch (PIB).

Crux cordis. In $56.7 \%$ of the specimens, the circumflex branch of the left coronary artery went beyond the crux cordis, either directly or through branches. In $40 \%$, it reached the crux cordis but did not go beyond it, and in only $3.3 \%$, it ended before reaching the crux cordis.

Apex of the heart. The branches present at the apex of the heart always belonged to branches of the left coronary artery.

The paraconal interventricular branch finished its subpericardial course before reaching the apex of the heart in $6.7 \%$ of the specimens, at the apex in $36.7 \%$ or passed through the apex and ended at the subsinuosus interventricular sulcus in $56.7 \%$.

It was found that the subsinuosus interventricular branch was to finish before reaching the apex of the heart 
in $70 \%$ of specimens or at the apex $(16.7 \%)$, or go beyond the apex in the remaining specimens.

The region of the apex of the heart presented predominance of the paraconal interventricular branch in 20 cases $(66.7 \%)$ and predominance of the subsinuosus interventricular branch in one case (3.3\%). Both branches of the left coronary artery were present in eight specimens $(26.7 \%)$, while in one case $(3.3 \%)$, both of the branches ended before reaching the apex.

Margins. The left marginal branch of the circumflex branch was present in all the cases, while the right marginal branch was observed in $93.3 \%$.

In 16 cases (53.3\%)he end of the left marginal branch was found to be before reaching the apex and in 14 cases $(46.7 \%)$ was at the apex. The end of the right marginal branch was found before reaching the apex in $96.4 \%$ and at the apex in $6 \%$.

Artery lengths. The mean lengths of the arteries of the heart were: right coronary artery $3.8 \mathrm{~cm}$ (range: $1.0-7.2 \mathrm{~cm}$ ); paraconal interventricular artery $6.9 \mathrm{~cm}$ (range: $5.6-8.7$ $\mathrm{cm}$ ); circumflex artery $4.73 \mathrm{~cm}$ (range: $3.3-6.7 \mathrm{~cm}$ ); and subsinuosus interventricular artery $3.4 \mathrm{~cm}$ (range: $1.1-6.2$ cm) (Fig.2).

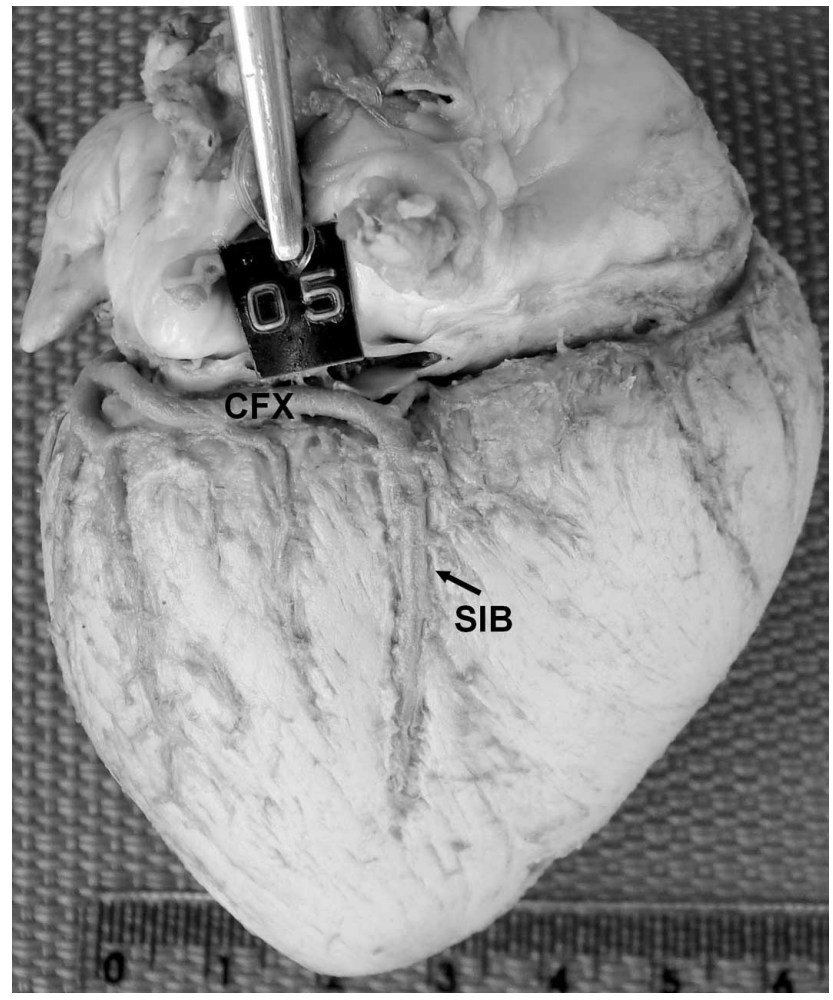

Fig. 2. Circunflex (CFX) and subsinuosus interventricular branch (SIB).
Number of ventricular branches in each artery. Considering all the specimens studied, the left coronary artery issued 581 ventricular branches (74.8\%) through its paraconal interventricular and circumflex branches (including the subsinuosus interventricular branch), while the right coronary artery issued 196 ventricular branches (25.2\%).

While the right coronary artery (Fig. 3) provided $48.4 \%$ of the arterial supply to the right ventricle, the left coronary artery provided $51.6 \%$ to the same ventricle. The arterial supply to the left ventricle depended exclusively on the left coronary artery through its branches $(100 \%)$.

In each heart, the mean number of branches from the left coronary artery was 23.5 and it was 10.7 from the right coronary artery.

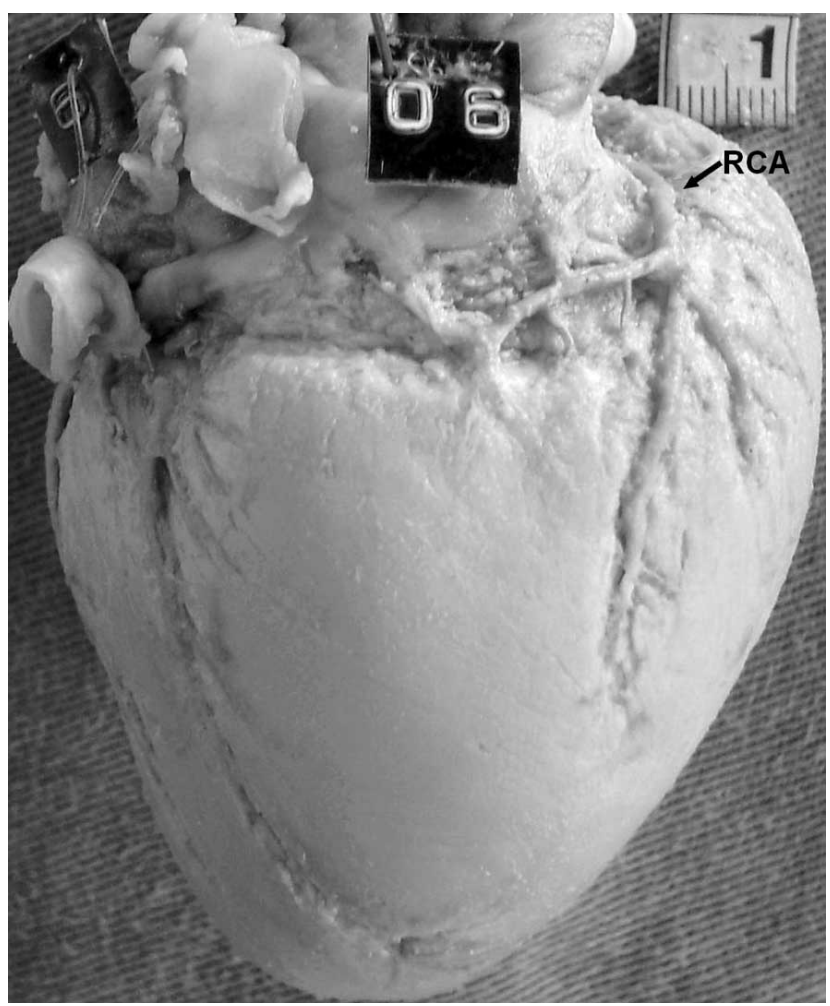

Fig. 3. Right coronary artery (RCA).

\section{DISCUSSION}

The reference points that are most acceptable and that best define which artery is dominant in the hearts of dogs consist of determining which artery goes beyond the crux cordis, either directly or through its short or long branches, and where the subsinuosus interventricular branch comes from. From these parameters, the arterial pattern in the hearts of dogs presents left dominance (100\%). 
The layout of the arteries at the apex of the heart is totally dependent on the left coronary artery, through its paraconal interventricular and subsinuosus branches.

In the hearts of dogs, all the criteria cited in the literature as possible parameters confirm the left dominance. Our suggestion of the difference between the summed lengths of the coronary arteries and their branches also confirms this: left coronary artery, $15.03 \mathrm{~cm}$ or $79.8 \%$, versus right coronary artery, $3.8 \mathrm{~cm}$ or $20.2 \%$. The number of ventricular branches issued by the branches of the left coronary artery (74.8\%) is much greater than the number from the right coronary artery $(25.2 \%)$.

In humans, the right coronary artery is dominant: 73.5\% (Didio \& Wakefield, 1975), 70\% (Cavalcanti et al., 1995), 89\% (Nerantzis et al., 1996) and 60\% (Kaimkhani et al., 2005).
Thus, researchers who use coronary arteries from dogs in experiments with a view to their future application in human coronary arteries need to be aware that the distribution pattern of the coronary arteries is different between humans and dogs. We did not find any similar study on animals in the literature with which we could have made comparisons.

In conclusion the subsinuosus interventricular branch comes from the circumflex branch of the left coronary artery. The circumflex branch goes beyond the crux cordis either directly or through its branches. The paraconal interventricular branch is predominantly present at the apex of the heart. Issuing of ventricular branches, including to the right ventricle, is done predominantly by branches of the left coronary artery. In the hearts of dogs, the left coronary artery is dominant. The arterial supply pattern in the hearts of dogs is different from the arterial supply pattern in human hearts.

OLIVEIRA, C. L. S.; DAVID, G. S.; CARVALHO, M. O.; DORNELAS, D.; ARAÚJO, S.; DA SILVA, N. C.; ; RUIZ, C. R.; FERNANDES, J. R. \& WAFAE, N. Indicadores anatómicos de la dominancia en las arterias coronarias de perros. Int. J. Morphol., 29(3):845-849, 2011.

RESUMEN: En los corazones humanos la dominancia coronaria es derecha. Sin embargo, no encontramos referencias en la literatura sobre los indicadores de esta dominancia en perros. Utilizamos 30 corazones de perros de ambos sexos y raza mixta, fijados en formaldeído al 10\%. Las ramas de las arterias coronarias fueron disecadas con especial atención a los niveles considerados como referencias. En 96,7\% de los corazones, la rama circunfleja de la arteria coronaria izquierda excedió o llegó a la crux cordis. La arteria interventricular subsinuosa, terminó antes de llegar al ápice en 21 casos, en el ápice en 5 casos y después del ápice en 4 casos. La arteria interventricular paraconal, terminó antes de llegar al ápice en 2 casos, en el ápice en 11 casos y después del ápice en 17 casos. La región del ápice del corazón estaba irrigada por ramas de la arteria coronaria izquierda a través de la rama interventricular paraconal o a través de los dos ramas interventriculares. La longitud media y el número de ramas ventriculares de la arteria coronaria izquierda son más grandes que las ramas de la arteria coronaria derecha. La rama interventricular subsinuosa es una rama de la rama circunfleja de la arteria coronaria izquierda. En los corazones de los perros, sin embargo, la dominancia es izquierda. La norma de dominancia en los perros es diferente de la norma de dominancia en humanos encontrada en la literatura.

PALABRAS CLAVE: Morfologia; Corazón de perros; Circulación; Arterias coronarias.

\section{REFERENCES}

Baroldi, G. \& Scomazzoni, G. Coronary circulation in the normal and the pathologic heart. Office of the surgeon general. Washington D. C., Department of the Army, 1967.

Cavalcanti, J. S.; de Lucena Oliveira, M.; Pais e Melo, A. V. Jr.; Balaban, G.; de Andrade Oliveira, C. L. \& de Lucena Oliveira, E. Anatomic variations of the coronary arteries. Arq. Bras. Cardiol., 65(6):489-92, 1995.

Del Rio, C. L.; McConnell, P. I.; Kukielka, M.; Dzwonczyk, R.; Clymer, B. D.; Howie, M. B. \& Billman, G. E. Electrotonic remodeling following myocardial infarction in dogs susceptible and resistant to sudden cardiac death. J. Appl. Physiol., 104(2):386-93, 2008.
DiDio, L. J. \& Wakefield, T. W. Coronary arterial predominance or balance on the surface of the human cardiac ventricles. Anat. Anz., 137(1-2):147$58,1975$.

Han, B. \& Wei, M. Proximal coronary hemodynamic changes evaluated by intracardiac echocardiography during myocardial ischemia and reperfusion in a canine model. Echocardiography, 25(3):312-20, 2008.

Ilia, R.; Rosenshtein, G.; Weinstein, J.; Cafri, C.; Abu-Ful, A. \& Gueron, M. Left anterior descending artery length in left and right coronary artery dominance. Coron. Artery Dis., 12(1):77-8, 2001. 
OLIVEIRA, C. L. S.; DAVID, G. S.; CARVALHO, M. O.; DORNELAS, D.; ARAÚJO, S.; DA SILVA, N. C.; ; RUIZ, C. R.; FERNANDES, J. R. \& WAFAE, N. Anatomical indicators of dominance between the coronary arteries of dogs. Int. J. Morphol., 29(3):845-849, 2011

James, T. N. Anatomy of the coronary arteries. New York, Paul B. Hoeber, 1961.

Kaimkhani, Z. A.; Ali, M. M. \& Faruqi, A. M. Pattern of coronary arterial distribution and its relation to coronary artery diameter. J. Ayub. Med. Coll. Abbottabad., 17(1):40-3, 2005.

Kawasumi, H.; Satoh, N. \& Kitada, Y. Caldaret, an intracellular $\mathrm{Ca} 2+$ handling modulator, limits infarct size of reperfused canine heart. J. Pharmacol. Sci., 103(2):222-33, 2007.

Nerantzis, C. E.; Papachristos, J. C.; Gribizi, J. E.; Voudris, V. A.; Infantis, G. P. \& Koroxenidis, G. T. Functional dominance of the right coronary artery: incidence in the human heart. Clin. Anat., 9(1):10-3, 1996.

Schlesinger, M. J. Relation of the anatomic pattern to pathologic conditions of the coronary arteries. Arch. Pathol., 30:443, 1938.

Setty, S.; Zong, P.; Sun, W.; Tune, J. D. \& Downey, H. F. Hypoxia-induced vasodilation in the right coronary circulation of conscious dogs: role of adrenergic activation. Auton. Neurosci., 138(1-2):76-82, 2008.

Sukmawan, R.; Yada, T.; Toyota, E.; Neishi, Y.; Kume, T.; Shinozaki, Y.; Mori, H.; Ogasawara, Y.; Kajiya, F. \& Yoshida, K. Edaravone preserves coronary microvascular endothelial function after ischemia/ reperfusion on the beating canine heart in vivo. J. Pharmacol. Sci., 104(4):341-8, 2007.

Vieira, T. H.; Moura, P. C. Jr.; Vieira, S. R.; Moura, P. R.; Silva, N. C.; Wafae, G. C.; Ruiz, C. R. \& Wafae, N. Anatomical indicators of dominance between the coronary arteries in swine. Morphologie, 92(296):3-6, 2008.

Yada, T.; Shimokawa, H.; Hiramatsu, O.; Shinozaki, Y.; Mori, H.; Goto, M.; Ogasawara, Y. \& Kajiya, F. Important role of endogenous hydrogen peroxide in pacing-induced metabolic coronary vasodilation in dogs in vivo. J. Am. Coll. Cardiol., 50(13):1272-8, 2007.

\author{
Correspondence to: \\ Cristiane Regina Ruiz \\ Rua Roberto Koch, 34 - Ipiranga \\ CEP 04221-060 \\ São Paulo \\ BRAZIL
}

Email: crisruiz@saocamilo-sp.br

Received: 24-02-2011

Accepted: 20-06-2011 